\title{
PENGARUH EDUCATIONAL TOURISM EXPERIENCE TERHADAP KEPUASAN WISATAWAN DI KAMPUNG BATU MALAKASARI
}

\author{
Adi Hasdian \\ Heri Puspito Diyah Setyorini
}

Kampung Batu Malakasari is one of the main tourist destinations located in Bandung. The destination has interesting attractions and activities, where tourists not only traveled for leisure, but get educational value as well. There are also educational tour packages for tourists groups; especially schools that want to get learning experience. In 2014, the number of group of tourists who visited Kampung Batu Malakasari decreased by $10.83 \%$. Moreover, based on the pre-research on 30 respondents who was conducted in 2015, it was found that tourist satisfaction was low, particularly the satisfaction at the educational experience. The guest comments that were compiled by the management have also shown the similar result. In fact, the management already had a great effort in conducting activities in delivering a good educational experience. Hence, it is important to carry out research to discover the influence of the education experience for the tourist's satisfaction at Kampung Batu Malakasari. The independent variable in this research was educational tourism experience $(X)$ that consisted of attractions and events, resource specialists, affinity travel planner's tour and receptive operators. The dependent variable was the tourists' satisfaction (Y), which was the ratio of the value perceived with the value expected. The approach used for this research was a quantitative method by conducting the explanatory survey. The sample used for this research was 100 respondents with the simple random sampling technique. The data analysis and hypothesis testing used for this research is multiple-linear regression analysis. The results showed that the perceived education experience score was $74.06 \%$, while the expected educational experience score is $75.07 \%$. This score indicated that the response of the tourists' group to educational experience was at the "good" category. Likewise, the tourist's response group to tourist satisfaction had $99 \%$ as the score, where it was categorized as an "excellent," which means that the group was very satisfied. Based on the statistical results, simultaneously, the educational tourism experience effect gave $41.5 \%$ contribution to the tourists' satisfaction. Partially, only two dimensions had a significant effect to tourist satisfaction, namely attractions and events; and resource specialists.

Keywords: educational tourism experience, tourist satisfaction, Kampung Batu Malakasari

\section{PENDAHULUAN}

\subsection{Latar Belakang Penelitian}

Sektor pariwisata menjadi salah satu sektor yang dikembangkan oleh berbagai negara di dunia. Berbagai jenis usaha pariwisata kian bermunculan seiring meningkatnya minat masyarakat untuk berwisata. Fenomena tersebut terjadi dikarenakan banyak hal dan salah satunya adalah karena pariwisata memberikan banyak manfaat bagi berbagai pihak terkait, termasuk bagi wisatawan sendiri.

Pariwisata memberikan banyak manfaat atau keuntungan. terutama pada bidang ekonomi, sosial budaya, politik dan lingkungan hidup. Berbagai manfaat yang diperoleh tersebut menjadi peluang bagi para pebisnis untuk turut bagian dalam sektor ini.
Persaingan yang terjadi di industri ini pun semakin ketat. Perusahaan maupun organisasi yang bergerak dalam industri tersebut harus bergerak cepat dalam mencari dan mempertahankan pelanggan-pelanggannya atau dikatakan sebagai wisatawan.

Maka dari itu, salahsatu strategi yang gencar dilakukan oleh perusahaan-perusahaan maupun organisasi tersebut adalah mulai menciptakan nilai yang akan diperoleh wisatawan nantinya, yang diharapkan menjadi keunikan dan keunggulan tersendiri sehingga mampu bersaing dengan yang lainnya. Ferrel dan Hartline (2011, hlm. 370) mengemukakan bahwa kita dapat lebih memahami bagaimana strategi pemasaran suatu perusahaan dapat dirancang untuk mengoptimalkan nilai pelanggan. 
Edukasi menjadi salahsatu nilai yang diciptakan untuk mendapatkan keunggulan bersaing. Oleh karena itu, mulai berkembang wisata edukasi yang kian bermunculan di berbagai tempat.

Masalah yang timbul dari fenomena semakin beragamnya aktivitas yang ditawarkan oleh berbagai destinasi wisata adalah tingkat kunjungan wisatawan yang fluktuatif. Semakin beragamnya aktivitas dan atau daya tarik wisata yang ditawarkan oleh destinasi wisata memberikan banyak pilihan bagi wisatawan dalam menentukan destinasi yang akan dikunjungi. Hal tersebut tentu menjadi keuntungan tersendiri bagi wisatawan yang mana selalu ingin merasakan pengalaman baru di destinasi yang berbeda. Sehingga destinasi wisata akan mengalami kesulitan memperoleh wisatawan yang puas, karena wisatawan memiliki kesempatan untuk membandingan dengan destinasi lain yang memiliki nilai serupa.

Salahsatu destinasi di Kabupaten Bandung yang memiliki permasalahan dengan tingkat kepuasan wisatawan adalah Kampung Batu Malakasari.

Setelah dilakukan pra-penelitian pada 30 wisatawan study tour, ditemukan bahwa salah satu penyebab turunnya kunjungan wisatawan adalah wisatawan yang berkunjung belum sepenuhnya merasakan puas dengan yang ditawarkan oleh Kampung Batu Malakasari baik dari segi daya tarik wisata, pelayanan serta pengalaman wisata edukasi yang didapatkan. Berikut data yang diperoleh melalui perhitungan menggunakan garis kontinuum.

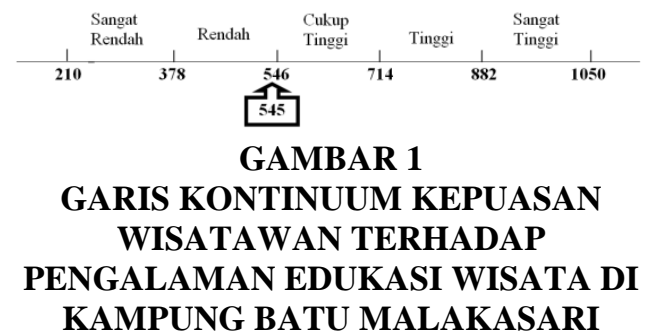

Selain itu, permasalahan kepuasan pun terlihat dari komentar wisatawan grup yang berkunjung ke Kampung Batu Malakasari dalam guest comment yang dibagikan pada setiap wisatawan grup, banyak dari pengunjung yang belum puas. Ketidakpuasan itu dapat dilihat dari $65 \%$ komentar yang masih negatif yang ditujukan pada atraksi wisata dan unsur edukasi yang terkandung serta kemampuan pemandu dalam menyampaikan informasi kepada wisatawan.

Menurut Bi-Jen Fan dalam Obonyo (2011, hlm. 37) menyatakan bahwa pengalaman adalah kunci faktor dalam hal motivasi untuk kembali berpartisipasi, untuk kepuasan dan loyalitas pelanggan. Pengalaman baik yang didapatkan wisatawan akan memberikan kepuasan kepada wisatawan, dan pengalaman yang buruk berdampak pada ketidakpuasan wisatawan.

Berdasarkan latar belakang yang diungkapkan, maka dari itu peneliti perlu melakukan suatu penelitian mengenai 'Pengaruh Educational Tourism Experience Terhadap Kepuasan Wisatawan di Kampung Batu Malakasari' Survey dilakukan pada wisatawan grup sekolah yang mengikuti paket wisata edukasi di Kampung Batu Malakasari.

\subsection{Rumusan Masalah}

1. Bagaimana gambaran Educational Tourism Experience di Kampung Batu Malakasari

2. Bagaimana gambaran Kepuasan Wisatawan di Kampung Batu Malakasari

3. Bagaimana pengaruh Educational Tourism Experience Terhadap Kepuasan Wisatawan di Kampung Batu Malakasari

\subsection{Tujuan Penelitian}

1. Untuk memperoleh temuan mengenai Educational Tourism Experience di Kampung Batu Malakasari

2. Untuk memperoleh temuan mengenai Kepuasan Wisatawan di Kampung Batu Malakasari

3. Untuk memperoleh temuan mengenai pengaruh Educational Tourism Experience terhadap Kepuasan Wisatawan di Kampung Batu Malakasari

\subsection{Kegunaan Penelitian}

\subsubsection{Kegunaan Penelitian Teoritik}

Hasil penelitian ini diharapkan dapat memperluas kajian ilmu tentang educational tourism experience dan kepuasan wisatawan 
sehingga penelitian ini dapat berguna bagi para mahasiswa Manajemen Pemasaran Pariwisata pada umumnya dan bagi penulis pada khususnya, serta dapat memberikan saran bagi peneliti untuk perbaikan pada penelitian selanjutnya.

\subsubsection{Kegunaan Penelitian Praktik}

Diharapkan hasil penelitian ini dapat membantu memecahkan masalah kepuasan wisatawan di Kampung Batu Malakasari melalui educational tourism experience agar kepuasan wisatawan semakin tinggi dan lebih baik lagi.

\section{KAJIAN PUSTAKA \\ 2.1 Konsep Educational Tourism Experience dalam Pemasaran \\ Pariwisata \\ Menurut Cohen dalam Raju (2009, hlm.} 53) telah menyarankan tipologi kognitif yang normal untuk menggambarkan apa arti perjalanan untuk setiap orang yang berbeda. Dengan demikian pariwisata bisa berupa Recreation, Diversionary, Experiential, Eksperimental dan Eksistensial.

Pariwisata bukan suatu industri yang menghasilkan produk berupa barang yang dapat dibawa oleh wisatawan untuk digunakan maupun diberikan sebagai hadiah bagi orang lain. Namun, pariwisata menyampaikan produk wisatanya melalui penyedia jasa kepada wisatawan sehingga kedua unsur tersebut memberikan pengalaman pada wisatawan.

Breejen (2007, hlm. 1418) menyatakan bahwa pengalaman adalah sebuah konsep yang kompleks dengan banyak dimensi, dipengaruhi oleh variabel situasional dan personal, dan terdiri dari banyak karakteristik.

Pengalaman merupakan konsep yang muncul pada pasca era modern ini. Carù and Cova dalam Dirsehan dan Yalcin (2011, hlm. 79) mengutarakan pengalaman (experience) merupakan suatu kategori tawaran baru atau keempat yang ditambahkan pada barang, produk, dan pelayanan beradaptasi dengan kebutuhan konsumen di era pasca modern.

Pine dan Gilmore (1999, hlm. 31) menawarkan empat jenis pengalaman konsumen: educational, entertainment, esthetic, escapist dan disebut sebagai " $4 E S$ ". 4ES bervariasi dalam hal keterlibatan dan penyerapan-perendaman dimensi aktif-pasif yang bersinggungan untuk menghasilkan kuadran. Keterlibatan aktif-pasif memerlukan tingkat partisipasi konsumen dalam penciptaan pengalaman yang menghasilkan penawaran.

Menurut Williams (2010) dalam artikelnya mengatakan bahwa pariwisata pendidikan adalah kegiatan wisata yang dilakukan oleh orang-orang yang melakukan liburan semalam dan mereka yang melakukan sebuah perjalanan untuk pendidikan dan pembelajaran, baik itu merupakan bagian primer atau sekunder dari perjalanan mereka.

Towner (1996, hlm. 115) menyatakan dengan benar, dari awal tentang wisata pendidikan dan pembelajaran dapat berlangsung baik secara formal maupun informal tergantung pada motivasi individu dan jenis pengalaman yang diminta.

The Canadian Tourism Commission dalam Ritchie (2003, hlm. 14) mencatat bahwa ada dua komponen utama untuk menyediakan sisi dari wisata : yaitu produk wisatawan utama dan elemen pendukung. beragam organisasi mengkombinasikan ke dalam bentuk utama educational tourism experience.

Ritchie (2003, hlm. 14) mengemukakan bahwa Educational tourism experience di dalamnya termasuk attractions and events, resource specialists, affinity travel planners, dan tour and receptive operators.

\subsection{Kepuasan Wisatawan}

Kepuasan wisatawan dilihat dari konsep kepuasan pelanggan. Kotler Dan Keller (2012, hlm. 128) menyebutkan secara umum, kepuasan adalah perasaan seseorang senang atau kecewa yang dihasilkan dari membandingkan kinerja suatu produk yang dirasakan (atau hasil) dengan harapan. Sementara, menurut James Barnes dalam Peppers dan Rogers (2011, hlm. 31), satisfaction is tied to what the customer gets from dealing with a company as compared with what he has to commit to those dealings or interactions.

Sedangkan menurut Hoyer dan Macinnis (2010, hlm. 279) Kepuasan adalah Perasaan yang terjadi ketika konsumen membuat evaluasi positif atau merasa senang dengan keputusan mereka.

Menurut Kotler dan Armstrong (2012, hlm. 6) kebutuhan dan keinginan konsumen 'dipenuhi melalui penawaran pasar. beberapa kombinasi dari produk, layanan, informasi, atau pengalaman yang ditawarkan ke pasar untuk memenuhi kebutuhan atau keinginan. 
Ratnasari dan Aksa (2011, hlm. 117) menyebutkan bahwa kepuasan pelanggan dapat dipengaruhi oleh kualitas produk, kualitas pelayanan, emotional dan harga. Selain itu, pengalaman menjadi salahsatu faktor seperti yang disampaikan oleh Fornell, Bitner dan Hudson dalam Ai Cam (2011, hlm. 9) Sebagai perbandingan, kepuasan pelanggan kumulatif adalah evaluasi secara keseluruhan berdasarkan total pembelian dan pengalaman konsumsi dengan barang atau jasa dari waktu ke waktu.

Dari seluruh penyataan yang telah diungkapkan, maka untuk mengukur kepuasan dapat dilihat pada fungsi kepuasan sebagai berikut:

$\mathrm{S}=\mathrm{f}(\mathrm{P} / \mathrm{E})$

Keterangan :

$\mathrm{S}=$ Customer Satisfaction

$\mathrm{P}=$ Perceived Performance

$\mathrm{E}=$ Expectation

Dari fungsi tersebut, dapat dilihat hasilnya melalui persamaan berikut:

Jika $\mathrm{P}<\mathrm{E}$, maka pelanggan merasakan tidak puas

Jika $\mathrm{P}=\mathrm{E}$, maka pelanggan merasakan puas

Jika $\mathrm{P}>\mathrm{E}$, maka pelanggan merasakan sangat puas

\subsection{Paradigma Penelitian}

Paradigma penelitian yang merupakan cara pandang peneliti dalam melihat pengaruh educational tourism experience terhadap kepuasan wisatawan grup sekolah di Kampung Batu Malakasari pada gambar 2 dibawah ini.

GAMBAR 2

PARADIGMA PENELITIAN

PENGARUH EDUCATIONAL TOURISM EXPERIENCE TERHADAP KEPUASAN

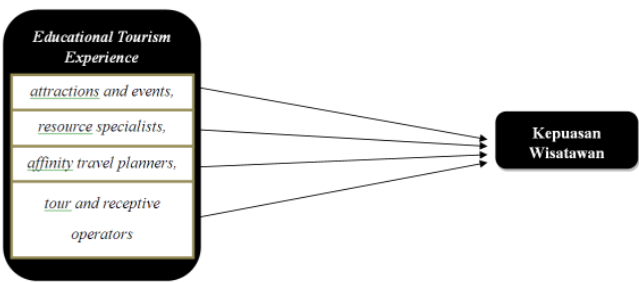
WISATAWAN DI KAMPUNG BATU
MALAKASARI

\subsection{Hipotesis}

Berdasarkan pemaparan tersebut, maka hipotesis dalam penelitian ini adalah terdapat pengaruh educational tourism experience yang terdiri dari attractions and events, resource specialists, affinity travel planners, dan tour and receptive operators baik secara simultan maupun parsial terhadap kepuasan wisatawan. III. METODE PENELITIAN

\subsection{Objek Penelitian}

Variabel yang digunakan pada penelitian ini terdiri dari dua variabel. Variabel X sebagai Variabel Bebas (Independen), Variabel Y sebagai variabel terikat (dependen). Penelitian ini menganalisis variabel dependen yaitu educational tourism experience yang terdiri dari attractions and events, resource specialists, affinity travel planners dan tour and receptive operators. Variabel independen yaitu kepuasan wisatawan yang terdiri dari perceived preformance dan expected value.

Unit analisis dalam penelitian ini adalah sekolah yang mengikuti paket study tour di Kampung Batu Malakasari

\subsection{Metode Penelitian}

Jenis penelitian yang digunakan adalah penelitian deskriptif dan verifikatif, didasarkan pada variabel-variabel yang telah disebutkan sebelumnya.

\subsection{Metode Penarikan Sampel}

Ukuran sampel dihitung dengan menggunaan rumus Slovin (Husein Umar, 2010, hlm. 131) Berdasarkan rumus tersebut, dengan derajat kesalahan sebesar 10\%, maka jumlah responden yang dijadikan ukuran sampel dalam penelitian ini adalah 80 responden. Namun, untuk akurasi data maka sampel dijadikan sebanyak 100 responden.

\subsection{Teknik Pengumpulan Data}

Teknik pengumpulan data yang dilakukan dalam penelitian ini adalah:

1. Wawancara,

2. Kuesioner/ Angket, wisatawan.

3. Observasi,

4. Studi Literatur.

\subsection{Pengujian Validitas dan Reliabilitas}

Selanjutnya, kuesioner akan diuji terlebih dahulu sebelum didistribusikan kepada responden. Uji yang dilakukan adalah uji validitas dan reliabilitas. Berdasarkan uji yang dilakukan, maka diperoleh hasil bahwa dari 19 item pertanyaan, 14 item baik variabel $\mathrm{X}$ maupun $\mathrm{Y}$ dinyatakan valid dan 5 item dinyatakan tidak valid. Kemudian, kedua 
variabel dinyatakan reliabel setelah dilakukan uji reliabilitas.

\subsection{Pengujian Hipotesis}

Hipotesis harus melalui proses pengujian. Kemudian, metode analisis yang dilakukan dalam penelitian ini adalah metode analisis verifikatif, maka dilakukan teknik analis regresi berganda (multiple regression).

Analisis regresi berganda digunakan untuk mengukur pengaruh antara lebih dari satu variabel independen terhadap variabel dependen dan mengetahui hubungan positif atau negatif dari masing-masing variabel independen tersebut. Dan analisis tersebut dapat memprediksi nilai dari variabel dependen apabila nilai variabel independen mengalami kenaikan atau penurunan. Data yang digunakan biasanya berskala interval atau rasio. Lebih jelasnya dapat dilihat pada gambar 3 berikut: Sumber : Sugiyono (2014, hlm.191

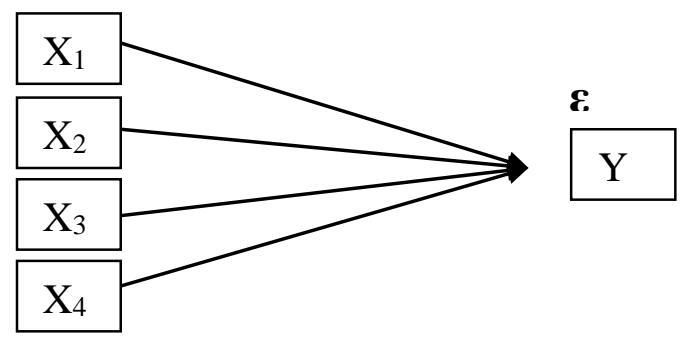

GAMBAR 3

REGRESI BERGANDA

Secara statistik, hipotesis yang akan diuji dalam rangka pengambilan keputusan penerimaan atau penolakan hipotesis dapat ditulis sebagai berikut:

\section{Secara Simultan}

Ho $: \rho=0$, berarti

Tidak terdapat pengaruh yang signifikan antara educational tourism experience terhaadap kepuasan wisatawan di Kampung Batu malakasari.

Ha $: \rho \neq 0$, berarti

Terdapat pengaruh yang signifikan antara educational tourism experience terhadap kepuasan wisatawan di Kampung Batu malakasari.

\section{Secara Parsial}

A. $\mathrm{H}_{0}: \rho=0$, artinya tidak terdapat pengaruh yang signifikan attractions and events terhadap kepuasan wisatawan
$\mathrm{H}_{\mathrm{a}}: \rho \neq 0$, artinya terdapat pengaruh yang signifikan attractions and events terhadap kepuasan wisatawan

B. $\mathrm{H}_{0}: \rho=0$, artinya tidak terdapat pengaruh yang signifikan resources specialists terhadap kepuasan wisatawan

$\mathrm{H}_{\mathrm{a}}: \quad \rho \neq 0$, artinya terdapat pengaruh yang signifikan resources specialists terhadap kepuasan wisatawan

C. $\mathrm{H}_{0}: \rho=0$, artinya tidak terdapat pengaruh yang signifikan affinity travel planners terhadap kepuasan wisatawan

$\mathrm{H}_{\mathrm{a}}: \rho \neq 0$, artinya terdapat pengaruh yang signifikan affinity travel planners terhadap kepuasan wisatawan

D. $\mathrm{H}_{0}: \rho=0$, artinya tidak terdapat pengaruh yang signifikan tour and receptive operators terhadap kepuasan wisatawan

$\mathrm{H}_{\mathrm{a}}: \rho \neq 0$, terdapat pengaruh yang signifikan tour and receptive operators terhadap kepuasan wisatawan.

\section{HASIL PENELITIAN DAN PEMBAHASAN}

4.1 Hasil Tanggapan Responden Terhadap Educational Tourism Experience yang Dirasakan di Kampung Batu Malakasari

Untuk melihat hasil tanggapan wisatawan grup tehadap educational tourism experience di Kampung Batu Malakasari, dapat dilihat melalui tabel. 1 rekapitulasi hasil tanggapan responden yaitu wisatawan grup terhadap educational tourism experience yang merupakan hasil dari pengumpulan data yang telah dipaparkan sebelumnya. 
TABEL. 1

REKAPITULASI HASIL TANGGAPAN
RESPONDEN TERHADAP
EDUCATIONAL TOURISM EXPERIENCE
YANG DIRASAKAN DI KAMPUNG
BATU MALAKASARI

\begin{tabular}{cccccc}
\hline No & $\begin{array}{c}\text { Sub } \\
\text { Variabel }\end{array}$ & $\begin{array}{c}\text { Total } \\
\text { Skor }\end{array}$ & $\begin{array}{c}\text { Jumlah } \\
\text { Item } \\
\text { Pertanyaa } \\
\mathrm{n}\end{array}$ & $\begin{array}{c}\text { Skor } \\
\text { Rata- } \\
\text { rata }\end{array}$ & $\%$ \\
\hline $\mathbf{1}$ & $\begin{array}{l}\text { Attractions } \\
\text { and Events }\end{array}$ & 1855 & 5 & 371 & 24.84 \\
$\mathbf{2}$ & $\begin{array}{l}\text { Resource } \\
\text { Specialists }\end{array}$ & 1084 & 3 & 361.3 & 24.19 \\
$\mathbf{3}$ & $\begin{array}{l}\text { Affinity } \\
\text { travel } \\
\text { planners } \\
\mathbf{4}\end{array}$ & 1120 & 3 & 373.3 & 25 \\
& $\begin{array}{l}\text { Tour and } \\
\text { receptive } \\
\text { operators }\end{array}$ & 1163 & 3 & 387.6 & 25.95 \\
\hline Total & 5222 & 14 & 1493. & 100 \\
\hline
\end{tabular}

Sumber : Pengolahan Data, 2015

Berdasarkan data pada tabel 1, menunjukan bahwa tanggapan responden yang memiliki penilaian tertinggi adalah pada tour and receptive operators sebesar $25.95 \%$ dan penilaian terendah terdapat pada resource specialists sebesar $24.19 \%$. tour and receptive operators mendapatkan nilai tertinggi karena pada sub variabel ini pemandu wisata adalah orang yang memberikan informasi serta pelayanan langsung kepada wisatawan, sehingga wisatawan merasakan pengalaman edukasi secara langsung. Resource specialists memiliki penilaian terendah karena sekolah tidak merasakan sentuhan para ahli secara langsung, pengalaman yang dirasakan pada sub variabel ini hanya pada saat berinteraksi dengan marketing dan terlihat pada bentuk fisik dari program atau paket yang dibuat.

Berdasarkan hasil perhitungan yang dilakukan, maka diketahui skor ideal yang diharapkan adalah 7000. Kemudian skor hasil dari perhitungaan tersebut yaitu 5222 atau sebesar $74.6 \%$. Ini menunjukan bahwa skor hasil dari tanggapan responden terhadap educational tourism experience yang dirasakan di Kampung Batu Malakasari terdapat pada kategori tinggi.

4.2 Hasil Tanggapan Responden Terhadap Educational Tourism Experience yang Diharapkan di Kampung Batu Malakasari

Berdasarkan pengolahan data, diperoleh hasil bagaimana tanggapan wisatawan grup terhadap educational tourism experience yang diharapkan dari semua sub variabel yang dihitung. Hasil tersebut digambarkan dalam tabel 2 berikut.

TABEL. 2

REKAPITULASI HASIL TANGGAPAN RESPONDEN TERHADAP

EDUCATIONAL TOURISM EXPERIENCE YANG DIHARAPKAN DI KAMPUNG BATU MALAKASARI

\begin{tabular}{|c|c|c|c|c|c|}
\hline No & $\begin{array}{c}\text { Sub } \\
\text { Variabel }\end{array}$ & $\begin{array}{l}\text { Total } \\
\text { Skor }\end{array}$ & $\begin{array}{c}\text { Jumlah } \\
\text { Item } \\
\text { Pertanyaan }\end{array}$ & $\begin{array}{c}\text { Skor } \\
\text { Rata- } \\
\text { rata }\end{array}$ & $\%$ \\
\hline 1 & $\begin{array}{l}\text { Attractions } \\
\text { and Events }\end{array}$ & 1904 & 5 & 380.8 & 25.42 \\
\hline 2 & $\begin{array}{l}\text { Resource } \\
\text { Specialists }\end{array}$ & 1139 & 3 & 379.7 & 25.34 \\
\hline 3 & $\begin{array}{l}\text { Affinity } \\
\text { travel } \\
\text { planners }\end{array}$ & 1100 & 3 & 366.7 & 24.48 \\
\hline \multirow[t]{2}{*}{4} & $\begin{array}{l}\text { Tour and } \\
\text { receptive } \\
\text { operators }\end{array}$ & 1112 & 3 & 370.7 & 24.74 \\
\hline & Total & 5255 & 14 & 1497.9 & 100 \\
\hline
\end{tabular}

Sumber : Pengolahan Data, 2015

Berdasarkan tabel 2, terlihat bahwa sub variabel yang memiliki harapan tertinggi dari wisatawan adalah pada attractions and events dengan $25.42 \%$, sedangkan yang memiliki penilaian terendah adalah affinity travel planners sejumlah $24.48 \%$. Kemudian, diketahui juga total skor dari ke empat sub variabel tersebut adalah sejumlah 5255 .

Berdasarkan hasil perhitungan, maka diketahui skor ideal yang diharapkan adalah 7000. Kemudian skor hasil dari perhitungaan tersebut yaitu 5255 atau sebesar $75.07 \%$. Ini menunjukan bahwa skor hasil dari tanggapan responden terhadap educational tourism experience yang diharapkan di Kampung Batu Malakasari terdapat pada kategori tinggi.

\subsection{Hasil Kepuasan Responden Terhadap} Educational Tourism Experience di Kampung Batu Malakasari

Tabel 3 berikut menunjukan bagaimana rekapitulasi kepuasan wisatawan terhadap educational tourism experience di Kampung Batu Malakasari dilihat dari skor masingmasing sub variabel yang diukur melalui rumus yang telah disepakati. 


\begin{tabular}{|c|c|c|c|c|c|}
\hline \multicolumn{6}{|c|}{$\begin{array}{c}\text { TABEL } 3 \\
\text { KEPUASAN RESPONDEN TERHADAP } \\
\text { EDUCATIONAL TOURISM EXPERIENCE } \\
\text { DI KAMPUNG BATU MALAKASARI }\end{array}$} \\
\hline \multirow[b]{2}{*}{ No } & \multirow[b]{2}{*}{$\begin{array}{c}\text { Sub } \\
\text { Variabel }\end{array}$} & \multicolumn{2}{|c|}{ Skor } & \multirow[b]{2}{*}{$\begin{array}{c}\text { Kepuasan } \\
\text { Wisatawan } \\
\text { Grup (P/E) }\end{array}$} & \multirow{2}{*}{$\begin{array}{c}\% \\
\text { Kepua- } \\
\text { san } \\
\text { Wisata- } \\
\text { wan } \\
\text { Grup } \\
\text { (P/E)x10 } \\
0\end{array}$} \\
\hline & & $\begin{array}{l}\text { Kenya- } \\
\text { taan } \\
\text { (P) }\end{array}$ & $\begin{array}{l}\text { Harapan } \\
\text { (E) }\end{array}$ & & \\
\hline 1 & $\begin{array}{l}\text { Attractions } \\
\text { and Events }\end{array}$ & 1855 & 1904 & 0.97 & 97 \\
\hline 2 & $\begin{array}{l}\text { Resource } \\
\text { Specialists }\end{array}$ & 1084 & 1139 & 0.95 & 95 \\
\hline 3 & $\begin{array}{l}\text { Affinity } \\
\text { travel } \\
\text { planners }\end{array}$ & 1120 & 1100 & 1.01 & 101 \\
\hline \multirow[t]{2}{*}{4} & $\begin{array}{l}\text { Tour and } \\
\text { receptive } \\
\text { operators }\end{array}$ & 1163 & 1112 & 1.04 & 104 \\
\hline & Total & 5222 & 5255 & 0.99 & 99 \\
\hline
\end{tabular}

Sumber : Pengolahan Data, 2015

Berdasarkan tabel 3, diketahui bahwa kepuasan wisatawan paling tinggi terhadap educational tourism experience adalah pada sub variabel tour and receptive operators sebesar $104 \%$. Ini berarti pemandu wisata sebagai pihak yang secara langsung memberikan pengalaman kepada wisatawan grup berhasil memberikan yang terbaik kepada wisatawan hingga merasa sangat puas.

Sedangkan, penilaian terendah terdapat pada sub variabel resource specialists yaitu sebesar $95 \%$. Ini dikarenakan orang-orang ahli yang turut dalam membentuk pengalaman wisata edukasi di Kampung Batu Malakasari tidak langsung menyampaikannya pada wisatawan, tetapi melalui program dan paket wisata edukasi yang disampaikan oleh pihak marketing dan juga pemandu wisata ketika melaksanakan wisata edukasi.

Secara keseluruhan, kepuasan responden memiliki nilai kepuasan sebesar 0.99 atau $99 \%$. Adapun cara mengetahui nilai kepuasan tersebut dapat ditentukan melalui Customer Satisfaction Index (CSI) yang terdapat pada tabel 4 berikut.

\section{TABEL 4 \\ KRITERIA NILAI CUSTOMER SATISFACTION INDEX INTERPRETATION

\begin{tabular}{cc}
\hline Angka Indeks & Interpretasi \\
\hline $\mathbf{X} \leq \mathbf{6 4} \%$ & Very Poor \\
$\mathbf{6 4} \%<\mathbf{X} \leq \mathbf{7 1} \%$ & Poor \\
$\mathbf{7 1} \%<\mathrm{X} \leq \mathbf{7 7} \%$ & Cause For \\
$\mathbf{7 7} \%<\mathrm{X} \leq \mathbf{8 0} \%$ & Concern \\
$\mathbf{8 0} \%<\mathbf{X} \leq \mathbf{8 4} \%$ & Borderline \\
$\mathbf{8 4} \%<\mathbf{X} \leq \mathbf{8 7 \%}$ & Good \\
$\mathbf{8 7} \%<\mathrm{X}$ & Very Good \\
\hline
\end{tabular}

Ket: $X=$ Angka indeks kepuasan / Nilai Kepuasan

Sumber : Customer Statisfaction Measurement : Statisfaction Index "www.leadershipfactor.com"

Berdasarkan tabel 4 tersebut. Maka nilai kepuasan sebesar $99 \%$ dapat dikatakan "Exccellent", artinya kepuasan wisatawan di Kampung Batu Malakasari telah mencapai tingkat tertinggi melebihi sangat baik. Dapat dikatakan bahwa wisatawan grup merasakan "Sangat Puas".

\subsection{Pengaruh Educational Tourism Experience Terhadap Kepuasan Wisatawan Di Kampung Batu \\ Malakasari}

4.4.1 Pengujian Hipotesis Dan Uji Signifikansi Secara Simultan (Uji F)

Uji F digunakan untuk mengetahui besar pengaruh keseluruhan variabel independen terhadap variabel dependen secara simultan. Uji F dapat dilakukan dengan membandingkan $\mathrm{F}_{\text {hitung }}$ dengan $\mathrm{F}_{\text {tabel. }}$ Tabel 5 berikut memperlihatkan hasil uji $\mathrm{F}$ yang dihitung dengan menggunakan program SPSS for windows ver. 20 dalam tabel ANOVA berikut.

TABEL 5

HASIL UJI F

ANOVA $^{\mathrm{a}}$

\begin{tabular}{|c|c|c|c|c|c|}
\hline Model & $\begin{array}{l}\text { Sum of } \\
\text { Squares }\end{array}$ & Df & $\begin{array}{l}\text { Mean } \\
\text { Square }\end{array}$ & $\mathrm{F}$ & Sig. \\
\hline $1 \quad$ Regression & 262.447 & 4 & 65.612 & 18.585 & $.000^{\mathrm{b}}$ \\
\hline $\begin{array}{c}\text { Residual } \\
\text { Total }\end{array}$ & $\begin{array}{l}335.391 \\
597.838\end{array}$ & $\begin{array}{l}95 \\
99\end{array}$ & 3.530 & & \\
\hline a. Dependent Var & & & & & \\
\hline
\end{tabular}

Sumber : Pengolahan Data, 2015 
Berdasarkan tabel 5, diperoleh hasil pengujian nilai $F$ sebesar 18.585 dengan signifikansi 0.000. nilai signifikansi lebih kecil dari taraf signifikansi sebesar 0.05. maka $\mathrm{H}_{\mathrm{o}}$ ditolak dan $\mathrm{H}_{\mathrm{a}}$ diterima. $\mathrm{H}_{\mathrm{a}}: \rho \neq 0$, artinya terdapat pengaruh yang signifikan antara educational tourism experience yang terdiri dari attractions and events, resource speciallists, affinity travel planners dan tour receptive operators terhadap kepuasan wisatawan di Kampung Batu Malakasari.

\subsubsection{Pengujian Hipotesis Dan Koefisien (Uji T)}

Uji t merupakan cara untuk mengetahui pengaruh dari masing-masing variabel independen terhadap variabel dependen, uji $\mathrm{t}$ dapat dilakukan dengan membandingkan $t_{\text {hitung }}$ dengan $t_{\text {tabel. }}$. Berikut hasil uji $t$ dengan menggunakan program SPSS for windows ver. 20 .

TABEL 6

HASIL UJI T

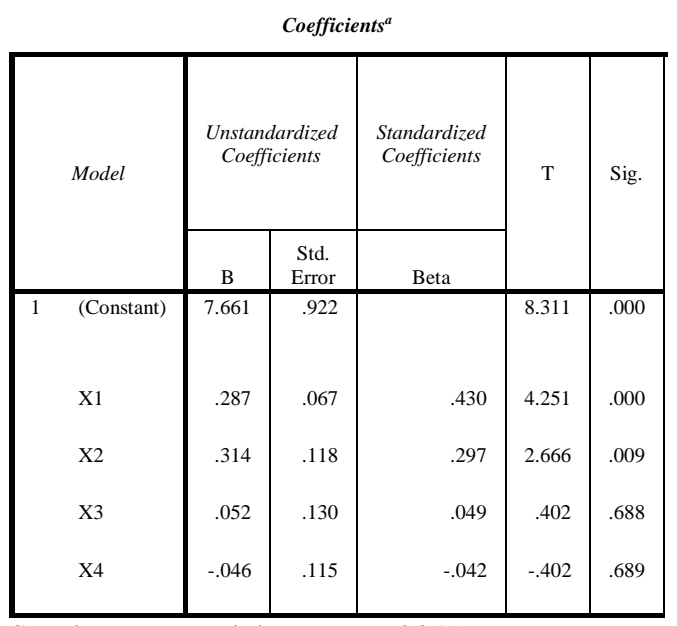

Sumber : Pengolahan Data, 2015

Berdasarkan tabel 6 Terlihat pengaruh dari masing-masing sub variabel educational tourism experience terhadap kepuasan wisatawan melalui t hitung. Untuk mengetahui $\mathrm{t}_{\text {tabel }}$ dapat dilihat pada degree of freedom (df) dan $\alpha=10 \%$ dengan uji dua pihak menjadi 5 $\%$. Hasil yang didapatkan melalui perbandingan $t_{\text {hitung }}$ dengan $t_{\text {tabel }}$ adalah sebagai berikut.
A. Terdapat pengaruh yang signifikan antara dimensi attractions and events terhadap kepuasan wisatawan dengan nilai signifikansi $0.000<0.05$, dan $\mathrm{t}_{\text {hitung }}, 4.251$ $>\mathrm{t}_{\text {tabel }}, 1.66105$, maka $\mathrm{H}_{\mathrm{o}}$ ditolak dan $\mathrm{H}_{\mathrm{a}}$ diterima.

B. Terdapat pengaruh yang signifikan antara dimensi resource specialists terhadap kepuasan wisatawan dengan nilai signifikansi $0.009<0.05$, dan $t_{\text {hitung }}, 2.666$ $>\mathrm{t}_{\text {tabel}}, 1.66105$, maka $\mathrm{H}_{\mathrm{o}}$ ditolak dan $\mathrm{H}_{\mathrm{a}}$ diterima.

C. Tidak terdapat pengaruh yang signifikan antara dimensi affinity travel planners terhadap kepuasan wisatawan dengan nilai signifikansi $0.688>0.05$, dan $t_{\text {hitung, }}$ $0.402<\mathrm{t}_{\text {tabel }}, 1.66105$, maka $\mathrm{H}_{\mathrm{o}}$ diterima dan $\mathrm{H}_{\mathrm{a}}$ ditolak.

D. Tidak terdapat pengaruh yang signifikan antara dimensi tour and receptive operators terhadap kepuasan wisatawan dengan nilai signifikansi $0.689>0.05$, dan $\mathrm{t}_{\text {hitung, }}-0.402<\mathrm{t}_{\text {tabel }}, 1.66105$, maka $\mathrm{H}_{\mathrm{o}}$ diterima dan $\mathrm{H}_{\mathrm{a}}$ ditolak.

Berdasarkan nilai $t_{\text {hitung }}$ dari keempat dimensi yang telah disebutkan diatas. Maka pada penelitian ini, dari empat dimensi, dua yang berpengaruh signifikan terhadap kepuasan wisatawan, yaitu attractions and events dan resource specialists. Hal ini terjadi karena kedua dimensi tersebut berisi bagaimana gambaran wisata edukasi dipersepsikan melalui kemenarikan kawasan dan orang-orang ahli yang membentuk program wisata edukasi sehinggu mudah dinilai oleh responden. Sedangkan affinity travel planners dan tour and receptive operators tidak berpengaruh signifikan terhadap kepuasan wisatawan.

\subsubsection{Model Persamaan Regresi Berganda Pengaruh Educational Tourism Experience Terhadap Kepuasan Wisatawan di Kampung Batu Malakasari}

Dalam penelitian ini, analisis regresi berganda dilakukan untuk mengetahui pengaruh educational tourism experience (X) yang terdiri dari attractions and events $\left(\mathrm{X}_{1}\right)$, resource specialists $\left(\mathrm{X}_{2}\right)$, affinity travel planners $\left(\mathrm{X}_{3}\right)$ dan tour and receptive operators $\left(\mathrm{X}_{4}\right)$ terhadap kepuasan wisatawan (Y). Persamaan regresi berikut menunjukan jika koefisien meningkat, maka variabel $\mathrm{Y}$ ikut 
meningkat dan jika koefisien menurun, maka variabel $\mathrm{Y}$ ikut menurun.

$\mathrm{Y}=\mathrm{a}+\mathrm{b} 1 \mathrm{X}_{1}+\mathrm{b} 2 \mathrm{X}_{2}+\mathrm{b} 3 \mathrm{X}_{3}+\mathrm{b} 4 \mathrm{X}_{4}+\mathrm{e}$

Keterangan :

$\begin{array}{ll}\mathrm{Y} & =\text { Kepuasan Wisatawan } \\ \mathrm{a} & =\text { Konstanta } \\ \mathrm{b} 1, \mathrm{~b} 2, \mathrm{~b} 3, \mathrm{~b} 4 & =\text { angka arah atau koefisien } \\ \text { regresi } & \\ \mathrm{X}_{1} & =\text { attractions and events } \\ \mathrm{X}_{2} & =\text { resource specialists } \\ \mathrm{X}_{3} & =\text { affinity travel planners } \\ \mathrm{X}_{4} & =\text { tour and receptive }\end{array}$

operators

Adapun persamaan regresi berganda untuk pengaruh educational tourism experience terhadap kepuasan wisatawan dirumuskan melalui persamaan berikut.

$$
\begin{gathered}
\mathrm{Y}=7.661+0.287 \mathrm{X}_{1}+0.314 \mathrm{X}_{2}+0.052 \mathrm{X}_{3}- \\
0.046 \mathrm{X}_{4}+\mathrm{e}
\end{gathered}
$$

Persamaan tersebut menunjukan bahwa nilai konstanta adalah sebesar 7.661, ini berarti bahwa apabila seluruh nilai sub variabel educational tourism experience diabaikan maka nilai kepuasan wisatawan akan tetap sebesar 7.661 .

Nilai 0.287 pada X1 menyatakan bahwa apabila koefisien regresi pada attractions and events ditambahkan satu satuan, maka nilai kepuasan wisatawan akan meningkat sebesar 0.287 , nilai 0.314 pada X2 menyatakan bahwa apabila nilai koefisien regresi pada resource specialists ditambahkan satu satuan, maka kepuasan wisatawan meningkat sebesar 0.314 , nilai 0.052 pada X3 menyatakan bahwa apabila koefisien regresi pada affinity travel planners ditambahkan satu satuan, maka kepuasan wisatawan meningkat sebesar 0.052 dan apabila nilai -0.046 pada X4 menyatakan apabila koefisien regresi pada tour and receptive operators ditambahkan satu satuan, maka nilai kepuasan wisatawan menurun sebesar -0.046 .

\subsection{Implikasi Hasil Penelitian}

\subsubsection{Temuan Penelitian Bersifat Teoritik}

1. Berdasarkan hasil temuan penelitian. Penulis memperkuat konsep educational tourism experience yang dikemukakan oleh Brent Ritchie (2003, hlm. 14) yang menyatakan bahwa educational tourism experience adalah bentuk utama dari produk wisatawan utama dan elemen pendukung yang dikombinasikan oleh beragam organisasi.

2. Berdasarkan hasil temuan penelitian. Penulis memperkuat konsep kepuasan wisatawan yang dikemukakan oleh Kotler dan Keller (2012, hlm. 128) yang menyebutkan secara umum, bahwa kepuasan adalah perasaan seseorang senang atau kecewa yang dihasilkan dari membandingkan kinerja suatu produk yang dirasakan (atau hasil) dengan harapan.

3. Berdasarkan hasil temuan penelitian. Penulis memperkuat konsep bahwa pengalaman wisata atau tourism experience berpengaruh pada kepuasan wisatawan, sesuai konsep yang dijelaskan oleh Bi-Jen Fan dalam Obonyo (2011, hlm. 37) menyatakan bahwa pengalaman adalah kunci faktor dalam hal motivasi untuk kembali berpartisipasi, untuk kepuasan dan loyalitas pelanggan.

4.5.2 Temuan Penelitian Bersifat Empirik

1. Berdasarkan hasil penelitian, diperoleh temuan mengenai educational tourism experience di Kampung Batu Malakasari, dimana mendapatkan tanggapan yang cukup baik dari para responden yang adalah wisatawan grup.

2. Berdasarkan hasil penelitian, diperoleh temuan mengenai kepuasan wisatawan di Kampung Batu Malakasari, dimana mendapatkan tanggapan yang sangat baik dari para responden yang adalah wisatawan grup.

3. Berdasarkan hasil penelitian, diperoleh temuan mengenai pengaruh educational tourism experience terhadap kepuasan wisatawan di Kampung Batu Malakasari, dimana terdapat pengaruh yang signifikan antara educational tourism experience di Kampung Batu Malakasari dan kepuasan wisatawan.

V. KESIMPULAN DAN SARAN

\subsection{Kesimpulan}

Berdasarkan hasil penelitian yang telah dilakukan dengan menyebarkan kuesioner kepada 100 responden yang merupakan 
wisatawan grup sekolah dari berbagai tingkat, dan juga setelah penguraian teori. Berikut dipaparkan hasil pengujian hipotesis tentang bagaimana pengaruh educational tourism experience terhadap kepuasan wisatawan di Kampung Batu Malakasari:

1. Educational tourism experience yang dirasakan yang terdiri dari attractions and events, resource specialists, affinity travel planners dan tour and receptive operators mendapat tanggapan yang baik dari wisatawan grup dan berada pada kategori tinggi. Sub variabel yang memiliki penilaian tertinggi terdapat pada tour and receptive operators. Ini dikarenakan pemandu wisata adalah orang yang memberikan informasi serta pelayanan langsung kepada wisatawan, sehingga wisatawan merasakan pengalaman edukasi secara langsung. Sementara, penilaian terendah terdapat pada resource specialists. Ini dikarenakan sekolah tidak merasakan sentuhan para ahli secara langsung, pengalaman yang dirasakan pada sub variabel ini hanya pada saat berinteraksi dengan marketing dan terlihat pada bentuk fisik dari program atau paket yang dibuat. Kemudian, tanggapan wisatawan grup terhadap Educational tourism experience yang diharapkan yang terdiri dari attractions and events, resource specialists, affinity travel planners dan tour and receptive operators berada pada kategoti tinggi yang berarti mendapat tanggapan yang baik dari wisatawan grup. Pada penelitian ini, sub variabel yang memiliki harapan tertinggi dari wisatawan adalah pada attractions and events, ini dikarenakan wisatawan grup menganggap bahwa daya tarik wisata adalah salahsatu hal pertama yang dirasakan penting untuk kegiatan wisata mereka, apalagi dalam hal ini nilai edukasi yang terdapat pada wahana yang terdapat di Kampung Batu Malakasari menjadi nilai lebih bagi wisatawan grup sekolah sehingga diharapkan sangat tinggi. Sedangkan harapan terendah terdapat pada affinity travel planners. Hal ini terjadi karena salahsatu yang menjadi perencana adalah sekolah sendiri yang dilibatkan dalam pengembangan kawasan oleh pengelola melalui mengisi komentar pada guest comment, menyusun paket sendiri sesuai keinginan dan kebebasan untuk menentukan nilai edukasi yang diharapkan pada paket wisata edukasi. Mereka tidak memiliki harapan yang tinggi untuk turut mengembangkan kawasan dan menyusun paket wisata, karena pada dasarnya wisatawan menginginkan apa yang mereka dapatkan sudah sesuai dan terima jadi, sehingga wisatawan tidak ikut terlalu jauh pada pengembangan kawasan, walaupun beberapa menganggap hal ini sebenarnya sangat penting.

2. Untuk kepuasan wisatawan sendiri didapatkan hasil melalui perbandingan antara pengalaman yang diterima dengan apa yang diharapkan. Maka kepuasan wisatawan terhadap educational tourism experience yang mendapatkan nilai tertinggi yaitu pada tour and receptive operators. Ini berarti pemandu wisata sebagai pihak yang secara langsung memberikan pengalaman kepada wisatawan grup berhasil memberikan yang terbaik kepada wisatawan hingga merasa sangat puas. Sementara penilaian terendah terdapat pada sub variabel resource specialists. Ini terjadi dikarenakan orang-orang ahli yang turut dalam membentuk pengalaman wisata edukasi di Kampung Batu Malakasari tidak langsung menyampaikannya pada wisatawan, tetapi melalui program dan paket wisata edukasi yang disampaikan oleh pihak marketing dan juga pemandu wisata ketika melaksanakan wisata edukasi. Sehingga dinilai kurang memuaskan wisatawan grup.

3. Educational tourism experience berpengaruh terhadap kepuasan wisatawan. Sebelumnya peneliti menjadikan pernyataan yang 
diungkapkan oleh Bi-Jen Fan dalam Obonyo (2011:37) yang menyatakan bahwa pengalaman adalah kunci faktor dalam hal motivasi untuk kembali berpartisipasi, untuk kepuasan dan loyalitas pelanggan sebagai acuan dalam penelitian ini. Maka dari itu penulis melakukan pengujian dan didapatkan hasil bahwa educational tourism experience berpengaruh secara signifikan terhadap kepuasan wisatawan di Kampung Batu Malakasari secara simultan. Sementara secara parsial, hanya dua sub variabel saja yaitu attractions and events dan resource speciallists yang terdapat pengaruh yang signifikan terhadap kepuasan wisatawan di Kampung Batu Malakasari.

\subsection{Saran}

Penelitian ini meneliti tentang bagaimana menciptakan kepuasan wisatawan melalui pengalaman yang dalam hal ini lebih spesifik yaitu educational tourism experience. Dari hasil yang diperoleh, masih terdapat halhal yang perlu diperbaiki karena nilai yang didapat terbilang masih kurang. Maka dari itu, penulis memberikan rekomendasi kepada perusahaan, dalam hal ini yaitu Kampung Batu Malakasari untuk meningkatkan kinerja

\section{DAFTAR PUSTAKA}

Ai Cam, Tran Thi. 2011. Explaining Tourist Satisfaction And Intention to Revisit Nha Trang, Vietnam. Vietnam. The Norwegian College of Fishery Science University of Tromso : Norway \& Nha Trang University

Den Breejen, L. 2007. The experiences of long distance walking: A case study of the west highland way in Scotland. Tourism Management, Vol. 28(6). hlm. 1417-1427

Dirsehan, T. dan Yalcin, M. 2011. Comparison Between Holistic Museum Visitor and Utilitarian Museum Visitors. International Journal of Marketing Studies. 3 (4). hlm. 78-94

Ferrel, O.C. dan Hartline, Michael D. 2011. Marketing Strategy Fifth Edition. USA : Cengage Learning

Husein, Umar. 2010. Desain Penelitian MSDM dan Perilaku Karyawan Paradigma perusahaan sehingga mampu meningkatkan kualitas dan memiliki keunggulan bersaing.

Berdasarkan hasil penelitian, terlihat bahwa dimensi yang memiliki pengaruh terhadap kepuasan wisatawan adalah attractions and events dan resource spesialists. Hal ini berarti perusahaan harus meningkatkan kinerjanya terutama pada dua dimensi tersebut agar kepuasan wisatawan semakin meningkat. Tabel 7 memaparkan rekomendasi penulis melalui program yang sebaiknya dilakukan oleh perusahaan.

\begin{tabular}{l} 
TABEL 7 \\
PEMETAAN REKOMENDASI PENULIS \\
DALAM MENINGKATKAN KEPUASAN \\
WISATA WAN GRUP DI KAMPUNG \\
BATU MALAKASARI \\
\begin{tabular}{|l|l|}
\hline Fokus & \multicolumn{1}{c}{ Deskripsi Program } \\
\hline & $\begin{array}{l}\text { 1. Memperbaiki wahana-wahana yang dirasa sudah } \\
\text { tidak layak; }\end{array}$ \\
& $\begin{array}{l}\text { 2. Melaksanakan pemeliharaan terhadap wahana- } \\
\text { wahana secara berkala; }\end{array}$ \\
Attractions \\
and Events & $\begin{array}{l}\text { 3. Meningkatkan kebersihan kawasan; } \\
\text { 4. Membuat keterangan yang berisi nilai edukasi } \\
\text { yang akan didapatkan wisatawan pada setiap }\end{array}$ \\
& $\begin{array}{l}\text { wahana; } \\
\text { 5. Menambahkan wahana baru yang sesuai dengan } \\
\text { tema wisata yang diusung; } \\
\text { 6. Dan lain sebagainya. }\end{array}$ \\
\hline 1. Para ahli (kordinator kebun, ternak, dan lainnya) \\
dalam setiap wahana mengadakan diskusi secara \\
berkala minimal 6 bulan sekali, guna meng-update \\
informasi yang akan disampaikan; \\
Resource \\
2. Para ahli yang menentukan dan membentuk \\
program wisata edukasi harus mengkordinasikan \\
programnya kepada seluruh karyawan; \\
3. Sebaiknya perusahaan memberikan atau \\
mengikutsertakan para ahli dalam sebuah \\
pelatihan terkait bidang yang digelutinya.
\end{tabular} \\
\hline
\end{tabular}

Sumber : Pengolahan data, 2015

Positivistik dan Berbasis Pemecahan Masalah. Jakarta : PT. RajaGrafindo Persada

Kotler, P. \& Amstrong, Gary. 2012. Principles of Marketing. $14^{\text {th }}$ edition. New Jersey: Pearson Prentice Hall

\& Keller, K. L. 2012. Marketing Management. $14^{\text {th }}$ edition. New Jersey: Pearson Prentice Hall

Obonyo, Moses. 2011. Experiential Marketing, Experiential Value, Purchase Behaviour and Customer Loyalty In The Telecoms Industry

Peppers, Don. dan Rogers, Martha. 2011. Managing Customer Relationship : A Strategic Frameworks Second Edition. USA : Jhon Wiley \& Sons

Pine Joseph, II, \& James H. Gilmore. 1999. The Experience Economy. United States of America: Harvard Business Press.

Raju, G.P. 2009. Tourism Marketing and Management. India: Manglam Publication. 
Ratnasari, Ririn Tri dan Aksa, Mastuti H. 2011. Manajemen Pemasaran Jasa. Bogor : Ghalia Indonesia

Ritchie, Brent. W. 2003. Aspect Of Tourism : Managing Educational Tourism. UK : Channel View Publications

Sugiyono. 2014. Metode Penelitian Kuantitatif, Kualitatif dan Kombinasi (Mixed Method). Bandung : Alfabeta
Towner, J. 1996. An Historical Geography of Recreation and Tourism in the Western World. 1540-1940. Chichester: John Wiley

Williams, Paul. 2010. Educational Tourism : Understanding The Concept, Recognising The Value,; Tourism Insight; Visit Britain/Tourism Together. Vol. 3 (1). Jan-Mar 